\title{
Socio-Economic, Demographic and Institutional Variables' Impact on the Development of Life Insurance in Sub-Saharan Africa and Madagascar
}

\author{
Momar Sylla Dieng ${ }^{1} \&$ Mouhamadou Fall ${ }^{1}$ \\ ${ }^{1}$ LARES - Gaston BERGER, University of Saint-Louis, Senegal \\ Correspondence: Momar Sylla Dieng, LARES - Gaston BERGER, University of Saint-Louis, Senegal. E-mail: \\ mdsylla22@yahoo.fr
}

Received: May 10, 2016

Accepted: June 15, 2016

Online Published: December 14, 2016

doi:10.5539/ijef.vn1p10

URL: http://dx.doi.org/10.5539/ijef.v9n1p10

\begin{abstract}
This study empirically analyzes the Socio-economic, Demographic and Institutional Variables' Impact on the Development of Life Insurance in Sub-Saharan Africa and Madagascar taking into account the Socio-economic and the Cultural structures of the set of countries. A mixed effect panel model is used to estimate the relationship between these variables and life insurance provisions, life insurance density and life insurance premium. covering the period 2000-2013, we found that financial development and urbanization are the only variables significantly related to all the variables of interest.
\end{abstract}

Keywords: life insurance, socio-economic and cultural structures, mixed effect panel model, Sub-Saharan Africa and Madagascar

\section{Introduction}

The rapid expansion of the life insurance market justifies the interest in this sector. The literature has, during the 2000 s, focused on the empirical analysis of factors impacting demand for life insurance. These studies use different measures and methodologies to explain the life insurance variation of a country (Lim \& Haberman, 2004; Hwang \& Greenford, 2005; Lenten \& Rulli, 2006) or a group of countries with or without the same features and belonging or not to the same geographical area (Brown \& Kim, 1993; Outreville, 1996; Ward \& Zurbruegg, 2000; Beck \& Webb, 2003; Kugler \& Ofoghi, 2005; Li et al., 2007; Kjosevski, 2012; Lee et al., 2013; Dieng \& Fall, 2015). Life insurance is, for the record, an insurance that guarantees a specific sum of money to a designated beneficiary upon the death of the insured or to the insured if he or she lives beyond a certain age. Life insurance policy offers a protection against the loss of income that would result if the insured passed away or a saving to the insured himself if he or she stays alive at a certain age well defined in the policy.

Ward and Zurbrugg (2000) and Kugler and Ofoghi (2005) use cointegration and causality test to investigate the relationship between economic development and the increase in life insurance premiums of the OECD countries and the United Kingdom countries, respectively. Outreville (1996), Beck and Webb (2003), Hwang and Greenford (2005), Kjosevski (2012), Lee et al. (2013), Dieng and Fall (2015) use panel data for the analysis of life insurance demand. The demand for life insurance is estimated in these studies considering these variables of interest: the penetration (Beck \& Webb, 2003; Kjosevski, 2012; Dieng \& Fall, 2015), the life insurance density (Beck \& Webb, 2003; Hwang \& Greenford, 2005; Kjosevski, 2012; Dieng \& Fall, 2015), the amount of premiums (Outreville, 1996; Lee et al., 2013) or the sum of nominal values and police dividends "life insurance in force" (Beck \& Webb, 2003). The table 1 of annex summarizes the main results found by these authors.

For Beck and Webb (2003), observed differences in results may be due to the methodology used or the group of countries which constitute the sample. Browne and Kim (1993) and Beck and Webb (2003) consider too that the premium and the penetration of life insurance are not a good measure of consumption of life insurance. The absence of regulatory costs and competition among companies, the types of products sold in a country where the cost of hedging could cause an increase in the total amount of insurance spending without translating greater consumption of populations' life insurance products.

However, few studies are mainly interested in African countries, which, unlike developed countries, have their own characteristics. Dieng and Fall's analysis (2015) studies the factors of life insurance consumption of the 
West African Economic and Monetary Union (WAEMU). The current article provides an extension to Dieng and Fall's article (2015) by considering a large sample of twelve (12) sub-Saharan African Francophone countries and Madagascar and covers the period 2000-2013. Moreover, taking into account different measures of the literature, an additional measure of insurance (provisions) is used to estimate demand in a logic of stock. Provisions allow covering future claims to the risks for which the premium was paid by policyholders. They are an analysis tools of company solvency. An increase in the provisions might well be seen as an increase in the consumption of life insurance. Finally, a mixed effect panel model was adopted to test the impact of economic and non-economic variables on the premium, penetration, density, and provision of life insurance. The mixed effect panel model will allow us to deal with the political, socio-economic and financial heterogeneity of our set of countries.

The rest of the article is organized as follows: the first section presents the own socio-economic and cultural context of the concerned countries. The chosen methodology is developed in the second section. The third section analyzes the results of our assessment.

\section{Life Insurance Demand and Socio-Economic and Cultural Structures of the Countries}

Life insurance helps to establish an intertemporal savings to meet two reasons: a contingency motive and a precautionary motive.

The pension motive refers to the necessity or the need for an individual to build up savings for future personal expenses. This form of life insurance is commonly called life insurance in case of survival (or annuity contract or simply life insurance).

The life insurance allows individuals to preserve the beneficiaries of the contract against the risks associated with their death. For precautionary reasons, deaths insurance products diminish the risks associated with the uncertainty of life. It also serves to index the legacy of a very specific person. This last feature is of a great importance when one takes into account certain considerations of ethnic, social and religious. The mandatory designation (of) recipient (s) can help mitigate conflicts often generated by the estate.

Besides the importance of life insurance on savings mobilization and patterns of foresight and precaution they provide to policyholders, they are struggling to grow in the WAEMU countries. In order to be attractive, insurance products should be adapted to the real needs of people. The allowances should be much higher than the premiums paid and guaranteed payment. The profitability of contracts is therefore favored by the availability of investments and the importance of profits earned on these investments. These are then partly paid into the account of the insured as compensation to its "profit sharing", the other part will be used to increase the revenue of the company. In sum, it is necessary for their extension, an efficient financial market, competitive products and accountable institutions anxious to meet deadlines.

However, there are, besides the life insurance, entities that offer almost similar or substitutable for life insurance products. Among other institutions one can include institution credits (banks and microfinance) and informal social support systems.

Credit institutions offer local services. Bank savings generates interest and facilitates access to credit investors. For some, the savings bank is less risky and more attractive (Kamega \& Planchet, 2012). The account feed is at the customer's convenience and he can benefit from the amount of savings account when he wants or, on the basis of a will, bequeathing his account balance to his heirs in case of sudden death.

The social support systems may take the form of tontine, surety group solidarity loan or a redistributive income system (Fall, 2014). Tontines are the most widespread social support system in the countries of Sub-Saharan Africa because of its participatory nature (Kamega, 2011; Bertomeu-Gilles et al., 2012). The members of a family, a group of friends, relatives or neighbors ... can simply decide to hold a tontine fund or each participant contributes periodically (weekly, monthly ...) an equal amount agreed by tacit consent. The pooled amount is redistributed to members after a period agreed in advance, either completely and each member receives the total accumulated paid or by lot, periodic and no possibility of redundancy, to determine in turn the person who will benefit amount. Tontines constitute both a source of credit and savings for members, based on trust, without intermediation costs or interest. In case of death of a Member, participation is entirely donated to her family. However, the shared responsibility of group lending systems reflects the fact that a group of individuals have for each other guarantor of a loan contracted individually (Lanha, 2002) while the redistributive systems involve a transfer of income from the richest to the poorest of a family or community, (Boulegue, 2011). These forms of informal (Note 1) finance are some safe ways to find investment funds and other possible substitutes to life insurance products. 
The lack of success of life insurance products in the sub-Saharan countries may also be likened to the inadequacy or lack of awareness policies, lax regulatory powers of the insurance markets or slow payment of compensation by companies (Ziguele, 2008a; Kamega \& Planchet, 2012). Furthermore, the prevalence of Muslims (Note 2) in most countries in the sample, makes, perhaps, hypothetical development of private life insurance schemes often deemed inadequate with sharia (Note 3).

The increase in life insurance demand requires, in addition to economic, institutional or demographic considerations, for "Africanization" of offered products. This is to provide individuals products that not only reflect their standard of living and meet their needs but also take into account the demographic structures of households.

\section{Data and Methodology}

This section, firstly, presents the variables used in the study and their sources. Secondly, we will conduct the study of the methodology and the presentation of demand models to estimate.

\subsection{Data}

Our article focuses on twelve African Sub-Saharan Francophone countries (Burkina Faso, Benin, Ivory Coast, Mali, Niger, Senegal, Togo, Cameroon, Chad, Central African Republic, Gabon and the Republic of Guinea) and Madagascar (Note 4). The study covers the period 2000 to 2013. In our analysis the following variables are retained: penetration, density, premiums and provisions as endogenous variables; GDP, financial development index (M2/GDP), employment ratio, young and old dependency ratios, life expectancy, health expenditure, interest rates, inflation, institutional factors (corruption, political stability and "voice and accountability") and religion as exogenous variables.

The study's data come mainly from four sources. The data on GDP, employment ratio, dependency ratios (young and old) and health expenditure are extracted from the database of the World Bank. The data on insurance, including density, penetration, bonuses, provisions are drawn from various FANAF annual reports (Federation of Societies of African National Insurance Law). Institutional variables are selected from the database of "the Worldwide Governance Indicators." Inflation, M2/GDP ratio and real interest rate for the seven WAEMU countries and Guinea are taken from the site of the WAMA (West African Monetary Agency).

The Real interest rate for the CEMAC countries (Chad, Cameroon, Central African Republic, Gabon) are calculated by adjusting lending rates to inflation (the rate of interest for deposits of one whole area): real rates interest $=($ interest rates of deposits - inflation) $/(1+$ inflation (Note 5)). Inflation and M2/GDP ratio for the CEMAC countries and Madagascar come from the World Bank website.

Missing values concerning the provision for the Madagascar of 2000, 2001 and 2002, and the Republic of Guinea, from 2000 to 2001 are approximated by taking respectively for Madagascar, the value of 2003, for Guinea, the value of 2002 .

The following table presents descriptive statistics of the variables of the study.

Table 1. Descriptive statistics

\begin{tabular}{|c|c|c|c|c|c|}
\hline Variable & Obs & Mean & Std. Dev. & Min & $\operatorname{Max}$ \\
\hline Premium & 182 & 10444.64 & 17457.57 & 41 & 103900 \\
\hline Penetration & 182 & 0.00182 & 0.00186 & .0001 & 0.00790 \\
\hline Density & 182 & 1135.887 & 1914.694 & 9 & 11200 \\
\hline Provision & 182 & 33224.05 & 60018.21 & 128.3 & 340300 \\
\hline M2/GDP & 182 & .2407656 & .0900705 & .0721808 & .48 \\
\hline Inflation & 182 & .0423235 & .0577219 & -.0897474 & .391 \\
\hline Real interest rate & 182 & .0279024 & .0940538 & -.23 & .5232372 \\
\hline health expenditure & 182 & .1039575 & .1385375 & .0267245 & .606 \\
\hline employment ratio & 182 & .6772452 & .0988846 & .468 & .858 \\
\hline dependency ratio old & 182 & .0605658 & .0131314 & .0470245 & .1096907 \\
\hline young dependency ratio & 182 & .8487017 & .092976 & .682704 & 1.059295 \\
\hline Urbanization & 182 & .3817519 & .1633086 & .16186 & .86658 \\
\hline GDP & 182 & $6.22 \mathrm{e}+12$ & $6.55 e+12$ & $6.51 e+11$ & $4.30 \mathrm{e}+13$ \\
\hline GDP/inhabitants & 182 & 370740.9 & 350439.5 & 25790.83 & 1477571 \\
\hline Life expectancy & 182 & 54.29296 & 5.107863 & 43.69232 & 64.69139 \\
\hline Voice and accountability & 182 & -.6608877 & .5552524 & -1.528735 & .3751929 \\
\hline Stabilité politique & 182 & -.6253258 & .8128143 & -2.374598 & .7401322 \\
\hline Corruption & 182 & -.7405714 & .3727972 & -1.446714 & 3099916 \\
\hline Religion & 182 & .5384615 & .4998937 & 0 (islam) & 1 (autres) \\
\hline
\end{tabular}


The chosen countries are, according to the IMF, considered HIPC (heavily indebted poor countries) characterized by a low level of income (370740.9 GDP/inhabitants on the avarage), an underdeveloped financial sector (.2407656 on the avarage), a still-very high population growth of around $2.8 \%$ on average (Note 6) and the lowest index of human development in the world (0.502) (Note 7).

Table 2 presents the main results of the literature on the direction of causality between the study variables and the demand for life insurance.

Table 2. Literature review

\begin{tabular}{|c|c|c|c|c|c|c|}
\hline \multirow[t]{2}{*}{ Variables } & \multicolumn{2}{|r|}{ Penetration } & \multicolumn{2}{|r|}{ Density } & \multicolumn{2}{|r|}{ Premiums } \\
\hline & sign & authors & sign & & sign & \\
\hline Income & + & $\begin{array}{l}\text { Beck and Webb (2003); } \\
\text { Kjosevski, 2012; }\end{array}$ & + & $\begin{array}{l}\text { Beck and Webb (2003); Hwang and } \\
\text { Greenford, 2005; Li et al. } 2007 \text {; } \\
\text { Kjosevski, 2012; }\end{array}$ & + & $\begin{array}{l}\text { Brown and Kim, 1993; } \\
\text { Outreville, 1996; Ward } \\
\text { and Zurbruegg, } 2000\end{array}$ \\
\hline $\begin{array}{l}\text { Financial development } \\
\text { Urbanisation }\end{array}$ & + & Beck and Webb, 2003 & $\begin{array}{l}+ \\
-\end{array}$ & $\begin{array}{l}\text { Beck and Webb, 2003; Li et al. 2007; } \\
\text { Dieng and Fall, } 2015\end{array}$ & + & Outreville, 1996 \\
\hline young dependency ratio & - & $\begin{array}{l}\text { Beck and Webb, 2003, } \\
\text { Dieng and Fall, } 2015\end{array}$ & - & Dieng and Fall, 2015 & & \\
\hline Old dependency ratio & + & $\begin{array}{l}\text { Beck and Webb, 2003; } \\
\text { Dieng and Fall, } 2015\end{array}$ & $\begin{array}{l}+ \\
-\end{array}$ & $\begin{array}{l}\text { Beck and Webb, } 2003 \\
\text { Sen, } 2008\end{array}$ & & \\
\hline total dependency ratio & & & + & Li et al. 2007; & + & Brown and Kim, 1993 \\
\hline Life expectancy & & & - & Beck and Webb, 2003; Li et. al. 2007 & & \\
\hline Interest rate & + & Beck and Webb, 2003 & - & Li et al. 2007 & & \\
\hline Inflation & - & Beck and Webb, 2003 & - & $\begin{array}{l}\text { Beck and Webb, 2003; Li et. al. 2007; } \\
\text { Kjosevski, 2012; }\end{array}$ & - & $\begin{array}{l}\text { Brown and Kim, 1993; } \\
\text { Outreville, 1996; }\end{array}$ \\
\hline Education & + & Kjosevski, 2012 ; & + & $\begin{array}{l}\text { Hwang and Greenford, 2005; } \\
\text { Kjosevski, } 2012\end{array}$ & & \\
\hline health expenditure & & & + & Kjosevski, 2012 & + & Brown and Kim, 1993 ; \\
\hline Employment & + & Dieng and Fall, 2015 & + & Dieng and Fall, 2015 & & \\
\hline Islam & - & Beck and Webb, 2003 & & & - & Brown and Kim, 1993 \\
\hline Voice and accountability & & & - & Dieng and Fall, 2015 & & \\
\hline
\end{tabular}

\section{Socio-Economic variables}

Income and financial development have a positive impact on the life insurance request (see Table 1). Even if the countries considered here are very poor and their financial market (mainly banking) uncompetitive, an improvement in these variables would enable populations to substitute luxury products to diversify their portfolio in safe and profitable investment. Life insurance often considered as a luxury product, the increasing per capita income could lead to an increase in demand for savings and investment precautionary reasons. While the improvement and development of the financial sector, in these regions, facilitate these investments and make the placements on these markets most profitable and life insurance products most attractive.

The results of the main analyses found a negative effect of inflation on demand for life insurance in accordance with their expectations. High inflation can lead to slower the economic growth, the overall product, and the deterioration of employment. It, therefore, disturbs the distribution of income making life insurance products less accessible and more expensive (Beck \& Webb, 2003; Li et al., 2007; Kjosevski, 2012; Dieng \& Fall, 2015).

The effect of the interest rate on life insurance is not determined in the literature. Beck and Webb (2003) found a positive relationship between these two variables, $\mathrm{Li}$ et al. (2007) a negative relationship while Browne and Kim (1996) neglect the effect of interest rates on variations in life insurance. A high level of interest rates makes the investment of life insurance companies more profitable and their products more attractive by increasing the profit participation of policyholders.

A more efficient social security system is expected to reduce consumption by reducing the insurance needs of the population to subscribe to a life insurance (Browne \& Kim, 1996; Beck \& Webb, 2003; Kjosevski, 2012; Dieng \& Fall, 2015). Like Kjosevski (2012), we will use health expenditure to GDP ratio as a measure of social security.

\section{$>$ Demographic variables}

According to Lewis (1986), the demographic structure of the household and the number of individuals in the household head load are key elements in purchasing decisions of life insurance policy. With a population growth 
rate around 3\%, the population in African countries is constituted of more young people $(84,87 \%)$ than old people $(6 \%)$. Households are often very broad, young in majority and under the responsibility of a single person. For most studies, the demand for life insurance would decrease with the increase of young people (young dependency ratio) (Beck \& Webb, 2003; Dieng \& Fall, 2015).

Urbanization favors the development of life insurance (Beck \& Webb, 2003). The concentration of population and enterprises in the big capitals of considered countries is likely to facilitate the distribution of insurance products by promoting people's access to companies and wide knowledge about offered products.

Life insurance is indexed on the mortality risk of the individual; an improvement of life expectancy of the population should have a negative impact on the life and death insurance demand and a positive impact on savings products. This suggests an ambiguous effect of life expectancy on the life insurance application (Browne \& Kim, 1993), Outreville, 1996), Beck \& Webb, 2003).

Analyses of the determinants of demand for life insurance detect a negative relationship between the belief in Islam and the consumption of life insurance (Browne \& Kim, 1993; Outreville, 1996; Beck \& Webb, 2003). However, Muslim countries considered in these studies are, on the whole, almost very rooted in religion, practicing the Shari'a (Note 8) in a strict way. While most countries in our sample advocate secularism, Muslim populations of the zone are more flexible - comparatively to countries practicing Sharia as Iran or Marocco - on issues relating to the purchase of a life insurance contract whose religious legality is still subject to discussion.

\section{$>$ Institutional variables}

Institutional development strengthens the confidence of agents to ensure the respect of contractual commitments to fight properly against corruption and reduce the asymmetries of information. The development of the institutional sector increases the profitability of investments of life insurance companies making them more attractive and accessible (Beck \& Webb, 2003; Kjosevski, 2011). In this study, we will use as institutional variables: corruption, voice and accountability and political stability.

In recent years, the African market is the yoke of investors. The implementation of new investment projects promotes the consideration of new types of risks. The number of insurance companies in these countries is steadily increasing (Note 9). The contributions collected by the only life insurance companies in the sample countries experienced an average increase of $74.1 \%$ from 2000 to 2013. This rapid growth of life insurance in thirteen years makes relevant research factors affecting growth.

The following table summarizes the assumptions associated with the selected variables.

Table 3. Assumptions associated with determinants of life insurance demand in the WAEMU countries

\begin{tabular}{ll}
\hline Variables & Expected Effets \\
\hline Income & Positive \\
Interest rate & Positive \\
Inflation & Négative \\
Financial development & Positive \\
Urbanization & Positive \\
young dependency ratio & Positive \\
old dependency ratio & Négative \\
Life expectancy & Négative \\
Gouvernance & Positive \\
Employment & Positive \\
religion & ambiguous \\
\hline
\end{tabular}

\subsection{Methodology}

We use a Generalized Linear Mixed Model (or GLMM) which includes both fixed and random effects (hence mixed models) to deal with the political, socio-economic and financial heterogeneity of our set of countries.

The general form of the model is:

$$
Y=X \beta+Z u+\varepsilon
$$

Where, $\mathrm{Y}$ is the $\mathrm{N} x 1$ vector of responses; $X$ is the $N x p$ matrix of the $p$ fixed-effects; $B p x 1$ column vector of the fixed-effects regression coefficients; $Z$ is the $N x q$ design matrix for the $q$ random effects; $u$ is a $q x 1$ vector of the random effects; $\varepsilon$ is the $N \times 1$ vector of errors.

Since we consider fours measures of life insurance, the specifications of the models to be estimated are: 


$$
\begin{aligned}
& \ln (\text { den })_{i t}=\left(\beta_{0}+u_{I J}\right)+\beta_{1} \beta g p d_{i t}+\beta_{2} m 2 / g p d_{i t}+\beta_{3} y d r_{i t}+\beta_{4} o d r_{i t}+\beta_{5} \ln (l e)_{i t}+\beta_{6} e r_{i t}+\beta_{7} h e_{i t} \\
& +\beta_{8} u p_{i t}+\beta_{9} i n f_{i t}+\beta_{10} \text { rir }_{i t}+\beta_{11} c c_{i t}+\beta_{12} v a_{i t}+\beta_{13} p s_{i t}+\beta_{14} r e l_{i t}+\varepsilon_{i j} \\
& \ln \left(\text { prem }_{i t}=\left(\beta_{0}+u_{I J}\right)+\beta_{1} \beta g p d_{i t}+\beta_{2} m 2 / g p d_{i t}+\beta_{3} y d r_{i t}+\beta_{4} o d r_{i t}+\beta_{5} \ln (l e)_{i t}+\beta_{6} e r_{i t}+\beta_{7} h e_{i t}\right. \\
& +\beta_{8} u p_{i t}+\beta_{9} i n f_{i t}+\beta_{10} \text { rir }_{i t}+\beta_{11} c c_{i t}+\beta_{12} v a_{i t}+\beta_{13} p s_{i t}+\beta_{14} r e l_{i t}+\varepsilon_{i j} \\
& \ln (\text { prov })_{i t}=\left(\beta_{0}+u_{I J}\right)+\beta_{1} \beta g p d_{i t}+\beta_{2} m 2 / g p d_{i t}+\beta_{3} y d r_{i t}+\beta_{4} o d r_{i t}+\beta_{5} \ln (l e)_{i t}+\beta_{6} e r_{i t}+\beta_{7} h e_{i t} \\
& +\beta_{8} u p_{i t}+\beta_{9} i n f_{i t}+\beta_{10} \text { rir }_{i t}+\beta_{11} c c_{i t}+\beta_{12} v a_{i t}+\beta_{13} p s_{i t}+\beta_{14} r e l_{i t}+\varepsilon_{i j} \\
& \text { pen }_{i t}=\left(\beta_{0}+u_{I J}\right)+\beta_{1} \beta_{g p d}+\beta_{2} m 2 / g p d_{i t}+\beta_{3} y d r_{i t}+\beta_{4} o d r_{i t}+\beta_{5} \ln (l e)_{i t}+\beta_{6} e r_{i t}+\beta_{7} h e_{i t} \\
& +\beta_{8} u p_{i t}+\beta_{9} i n f_{i t}+\beta_{10} \text { rir }_{i t}+\beta_{11} c c_{i t}+\beta_{12} v a_{i t}+\beta_{13} p s_{i t}+\beta_{14} r e l_{i t}+\varepsilon_{i j}
\end{aligned}
$$

\begin{tabular}{|c|c|c|c|c|}
\hline & Premium $^{\mathrm{a}}$ & Provision $^{\mathrm{a}}$ & Density $^{a}$ & penetration \\
\hline intercept & $\begin{array}{c}-34.722 \\
(4.47)^{* * * *}\end{array}$ & $\begin{array}{c}-23.272 \\
(3.20)^{* * *}\end{array}$ & $\begin{array}{c}-11.579 \\
(1.37)\end{array}$ & $\begin{array}{l}-0.009 \\
(0.87)\end{array}$ \\
\hline $\mathrm{GPD}^{\mathrm{a}}$ /capita & $\begin{array}{c}1.107 \\
(3.49) * * *\end{array}$ & $\begin{array}{c}1.306 \\
(3.85)^{* * *}\end{array}$ & $\begin{array}{l}0.337 \\
(1.10)\end{array}$ & $\begin{array}{l}0.000 \\
(1.01)\end{array}$ \\
\hline M2/GPD & $\begin{array}{c}2.683 \\
(2.98) * * *\end{array}$ & $\begin{array}{c}2.488 \\
(2.98) * * *\end{array}$ & $\begin{array}{c}2.526 \\
(2.65)^{* * * *}\end{array}$ & $\begin{array}{c}0.006 \\
(5.40)^{* * * *}\end{array}$ \\
\hline Employment & $\begin{array}{l}3.441 \\
(0.94)\end{array}$ & $\begin{array}{l}9.008 \\
(1.89)^{*}\end{array}$ & $\begin{array}{l}0.532 \\
(0.18)\end{array}$ & $\begin{array}{c}0.019 \\
(3.29)^{* * * *}\end{array}$ \\
\hline Young dependency ratio & $\begin{array}{l}2.563 \\
(1.35)\end{array}$ & $\begin{array}{l}1.139 \\
(0.67)\end{array}$ & $\begin{array}{c}5.279 \\
(2.58)^{* * * *}\end{array}$ & $\begin{array}{c}-0.007 \\
(3.02)^{* * * *}\end{array}$ \\
\hline Life expectency ${ }^{a}$ & $\begin{array}{c}5.819 \\
(3.15)^{* * * *}\end{array}$ & $\begin{array}{l}0.375 \\
(0.20)\end{array}$ & $\begin{array}{l}1.514 \\
(0.82)\end{array}$ & $\begin{array}{l}-0.003 \\
(1.20)\end{array}$ \\
\hline Old dependency ratio & $\begin{array}{l}-31.826 \\
(1.99)^{* *}\end{array}$ & $\begin{array}{r}24.039 \\
(1.57)\end{array}$ & $\begin{array}{l}-41.737 \\
(2.55) * *\end{array}$ & $\begin{array}{c}0.089 \\
(4.17)^{* * * *}\end{array}$ \\
\hline Urbanization & $\begin{array}{c}5.254 \\
(2.05)^{* *}\end{array}$ & $\begin{array}{c}16.757 \\
(6.38)^{* * *}\end{array}$ & $\begin{array}{c}10.632 \\
(4.04)^{* * *}\end{array}$ & $\begin{array}{c}0.013 \\
(3.71)^{* * * *}\end{array}$ \\
\hline Health expenditure & $\begin{array}{l}1.287 \\
(0.82)\end{array}$ & $\begin{array}{l}-2.819 \\
(1.72)^{*}\end{array}$ & $\begin{array}{l}0.370 \\
(0.25)\end{array}$ & $\begin{array}{l}0.001 \\
(0.39)\end{array}$ \\
\hline Inflation & $\begin{array}{c}2.235 \\
(2.17)^{* *}\end{array}$ & $\begin{array}{l}0.343 \\
(0.38)\end{array}$ & $\begin{array}{c}3.472 \\
(2.98)^{* * * *}\end{array}$ & $\begin{array}{r}-0.001 \\
(0.66)\end{array}$ \\
\hline Real interest rate & $\begin{array}{c}2.033 \\
(2.54)^{* *}\end{array}$ & $\begin{array}{c}1.197 \\
(1.68)^{*}\end{array}$ & $\begin{array}{c}2.009 \\
(2.24)^{* *}\end{array}$ & $\begin{array}{l}-0.001 \\
(1.16)\end{array}$ \\
\hline Corruption & $\begin{array}{l}0.201 \\
(1.01)\end{array}$ & $\begin{array}{l}0.274 \\
(1.53)\end{array}$ & $\begin{array}{c}0.428 \\
(1.90)^{*}\end{array}$ & $\begin{array}{l}-0.000 \\
(1.64)\end{array}$ \\
\hline Voice and accountability & $\begin{array}{l}-0.428 \\
(1.90)^{*}\end{array}$ & $\begin{array}{c}-0.893 \\
(4.32)^{* * *}\end{array}$ & $\begin{array}{l}-0.351 \\
(1.41)\end{array}$ & $\begin{array}{r}-0.000 \\
(0.03)\end{array}$ \\
\hline Political stability & $\begin{array}{l}0.156 \\
(1.47)\end{array}$ & $\begin{array}{l}0.021 \\
(0.22)\end{array}$ & $\begin{array}{c}0.224 \\
(1.87)^{*}\end{array}$ & $\begin{array}{l}0.000 \\
(1.41)\end{array}$ \\
\hline religion & $\begin{array}{l}0.362 \\
(0.40)\end{array}$ & $\begin{array}{l}-2.028 \\
(1.12)\end{array}$ & $\begin{array}{l}0.222 \\
(0.32)\end{array}$ & $\begin{array}{l}-0.003 \\
(1.82)^{*}\end{array}$ \\
\hline lns1_1_1_cons & $\begin{array}{l}0.301 \\
(1.07)\end{array}$ & $\begin{array}{c}1.124 \\
(3.96)^{* * *}\end{array}$ & $\begin{array}{r}-0.134 \\
(0.55)\end{array}$ & $\begin{array}{c}-5.903 \\
(20.10)^{* * *}\end{array}$ \\
\hline lnsig_e_cons & $\begin{array}{c}-0.980 \\
(17.34) * * *\end{array}$ & $\begin{array}{c}-1.133 \\
(20.00)^{* * *}\end{array}$ & $\begin{array}{c}-0.834 \\
(15.05)^{* * *}\end{array}$ & $\begin{array}{c}-7.665 \\
(134.68)^{* * * *}\end{array}$ \\
\hline $\begin{array}{r}\text { Wald chi2 }(15) \\
(\text { Prob }>\text { chi2 })\end{array}$ & $\begin{array}{c}349.48 \\
0.000\end{array}$ & $\begin{array}{c}465.46 \\
0.000\end{array}$ & $\begin{array}{c}167.87 \\
0.000\end{array}$ & $\begin{array}{c}286.14 \\
0.000\end{array}$ \\
\hline$N$ & 182 & 182 & 182 & 182 \\
\hline
\end{tabular}

With: gpd, GPD/capita; M2/GPD; re, Employment; ydr, Young dependency ratio; le, Life expectency; odr, Old dependency ratio; up, Urbanization; he, Health expenditure; inf, Inflation; rir, Real interest rate; cc, Corruption; va, Voice and accountability; ps, Political stability; rel, religion.

\section{Estimation Results}

This section presents the empirical results and interpretations on selected models.

Table 3. Estimation result

$* p<0.1 ; * * p<0.05 ; * * * p<0.01$.

${ }^{\mathrm{a}}$ variables expressed in log. 
The results of our estimation show that demand for life insurance in volume can be significantly explained by changes in income, financial development, urbanization, the old dependency ratio, life expectancy, the inflation, interest rate and degree of accountability of public power.

To $1 \%$, changes in income and financial development, the interest rate and the inflation rate increase subscriptions of respectively $1.107 \% ; 2.683 \% ; 2.033 \% ; 2.235 \%$. These results show the importance of socioeconomic factors on the life insurance application and corroborate most of some authors' ideas (Brown \& Kim, 1993; Outreville, 1996; Beck \& Webb, 2003; Li et al., 2007; Kjosevski, 2012; Lee et al., 2013; Dieng \& Fall, 2015 .... . Life insurance products, considered as luxury goods, is often held by individuals with substantial income. An increase in the population income level would lead to a better consideration of these products in their consumption patterns. Furthermore, financial development and the increase of interest rate offer to agents a wider choice of investment and easier access to financial services such as life insurance, with expectations of higher gain. By cons, although the authors predict a negative correlation between inflation and life insurance, the estimated premium suggests an even lower level, the latter to be considered harmful to the development of that area. The objective of controlling inflation, assigned to the monetary policies of those states, promotes business investment decisions while encouraging more households to invest their liquid assets in financial structures (Bruno \& Musso, 2000).

Urbanization is also positively related to the premium. An increase in the urban population of $1 \%$ leads to the premium improvement of 5.254\%. Insurance companies are especially concentrated in the capitals of African countries. Therefore, increasing urbanization in these regions facilitates the knowledge of agents, economic structures and access to insurance services that may increase insurance sales life while allowing businesses to reduce marketing costs (Beck \& Webb, 2003).

We also observe a positive relationship between the life expectancy and life insurance premium. A $1 \%$ increase in life expectancy increases the premium of 5.819\%. For Beenstock et al. (1986); Brown and Kim (1993); Outreville (1996) and Beck and Webb (2003) life expectancy is inversely related to the desire of protection against the risk of death. A high life expectancy is often equated with a higher level of life and savings insurance products.

For cons, the old age dependency ratio and participation factor and Accountability ("voice and accountability") negatively explain the life insurance premium.

Every $1 \%$ change from the old ratio of reduces premium of $31.826 \%$. The structure, often wide, households, social realities and the prevalence of youth in the population are all factors that can influence decisions savings or hedging. Older people in these countries are generally supported by their offspring and have a very low purchasing power likely to encourage the purchase of life insurance.

Similarly, a $1 \%$ change in the institutional factor of participation and accountability induces a decrease of $0.428 \%$ of the premium that may be due to, among others, the low level of institutional development of the countries concerned.

The young dependency ratio, employment, health expenditure, corruption and political stability are significantly related to the premium.

Unlike the estimate of the premium, employment and health expenses are significantly related to the provision. Life expectancy, the old age dependency ratio and inflation become insignificant. Employment is positively related to the provision. A $1 \%$ change in this ratio increases the supply of $9.008 \%$. The quality of employment favors, according to Hammond, Houston and Melander (1967), better consideration of life insurance products.

By cons, health spending negatively explains the life insurance provision. This result reinforces the arguments of Brown and Kim (1993); Ward and Zurbruegg (2000); Beck and Webb (2003), according to which, the increase in government spending on social protection reduces the need to protect individuals.

Changes in the density and penetration of life insurance are not explained by income, life expectancy, health expenditure or the institutional factor of participation and accountability. The employment ratio does not explain density. Corruption and political stability weakly and positively affect the density. This confirms the assumptions according to which an improvement in the governance of enterprises and political stability of countries are likely to create a climate of confidence and safety favorable to the life insurance market. While, only variables, financial development, employment, young and old dependency ratios, urbanization and religion, are significantly related to penetration, religion is weakly significant and negatively related to penetration. But this sign does not allow a proper conclusion as it shows a positive sign (but not significant) to the premium and the density and negative (not significant) for the provision. 


\section{Conclusion}

In this study, financial development and urbanization are the only variables significantly related to all the variables of interest. The rest of the results can be summarized as follows:

- The premium is explained: positively, by income, life expectancy, inflation and interest rates; and negatively by the aged dependency ratio and the accountability factor.

- The provision is related: positively by income, employment and interest rates; and negatively by health spending and the accountability factor.

- The density is positively correlated with the young expenditure ratio, inflation, interest rate and corruption; and negatively with the old dependency ratio.

- The penetration is positively correlated with employment and the ratio of old and negatively with the ratio of young and religion.

This result suggests that the observed differences may also be due to the types of factors used to measure the consumption of life insurance. Future research should work to provide answers to these questions: What econometric model is more suitable for the study of life insurance application? What variable mostly represents the request? The answer to these questions would help better understand the issue of development of life insurance products and the real constraints to its increase.

\section{References}

Ary, T., N., \& Plane, P. (2005). Performance et convergence des politiques économiques en zone franc. Revue Française D'Economie, 20(1), 235-268. https:/doi.org/10.3406/rfeco.2005.1569

Beck, T., \& Webb, I. (2003). Economic, demographic, and institutional determinants of life insurance consumption cross countries. The World Bank Economic Review, 17, 51-88. https:/doi.org/10.1093/wber/lhg011

Beenstock, M., Dickinson, G., \& Khajuria, S. (1996). The Determinants of Life Premiums: An International Cross-Section Analysis. Insurance: Mathematics and Economics, 5, 261-270. https:/doi.org/10.1016/0167-6687(86)90020-X

Bertomeu-Gilles, A., Briec, M., Kerdudo, M., Mebale, A., \& Merx, A. (2012). Défis techniques, financiers et commerciaux de l'assurance vie en Afrique subsaharienne francophone. Master actuariat premiere année, Université de Bretaggne Occid.

Boulègue, M. (2011). Demain, quelles politiques sociales? Vie Sociale, 4(4), 221-242. https:/doi.org/10.3917/vsoc.114.0221

Browne, M., \& Kim, K. (1993). An international analysis of life insurance demand. Journal of Risk and Insurance, 60, 616-34. https:/doi.org/10.2307/253382

Bruno, O., \& Musso, P. (2000). Volatilité de l'inflation et croissance économique. Revue Economique, 51(3), 693-701.

CIMA. (1996). Code des assurances des États membres de la CIMA. Broché.

Dieng, M., \& Fall, M. (2015). Les déterminants de la demande d'assurance vie: Le cas de l'UEMOA. Revue d'Economie Théorique et Appliquée, 5(1), 15-36.

Fall, M. (2014). Justice sociale et Couverture Maladie Universelle: Doctrine(s), enjeux et perspectives.

FANAF. (2000-2013). Marché de l'assurance en Afrique. Retrieved from http://www.fanaf.com

Hammond, J., Houston, B., \& Melander, R. (1967). Determinants of Household Life Insurance Premium Expenditures: An Empirical Investigation. Journal of Risk and Insurance, 34, 397-408. https:/doi.org/10.2307/250854

Hwang, T., \& Greenford, B. (2005). A Cross Section Analysis of the Determinants of Life Insurance Consumption in Mainland China,Hong Kong, and Taiwan. Risk Management and Insurance Review, 8, 103-125. https:/doi.org/10.1111/j.1540-6296.2005.00051.x

Kamega, A. (2011). l'assurance vie en Afrique subsaharienne francophone - Analyse et mesure des risques liés à la mortalité. Mémoire de Thèse, L'Université de LYON, Lyon.

Kamega, A., \& Planchet, F. (2012). Presentation du marche de l'assurancevie en afrique subsaharienne francophone. Insurance and Risk Management, 81(1-2), 38. 
Kjosevski, J. (2012). The Determinants of Life Insurance Demand in the central and southern Europe. International Journal of Economics and Finance, 4(3), 237-247. https:/doi.org/10.5539/ijef.v4n3p237

Kugler, M., \& Ofoghi, R. (2005). Does insurance promote economic growth? Evidence from the UK. Money Macro and Finance (MMF) Research Group Conference, 8.

Lanha, M. (2002). Résolution des problèmes d'information en micro-finance: Analyse à partir de la stratégie de Vital-Finance Bénin. Mondes en Développement, 119(3), 47-61. https:/doi.org/10.3917/med.119.0047

Lee, C. C., Lee, C. C., \& Chiu, Y. B. (2013). The link between life insurance activities and economic growth: Some new evidence. Journal of International Money and Finance, 32, 405-427. https:/doi.org/10.1016/j.jimonfin.2012.05.001

Lelart, M. (2002). L'évolution de la finance informelle et ses conséquences sur l'évolution des systèmes financiers. Monde en Développement, 30(1), 19-11. https:/doi.org/10.3917/med.119.0009

Lenten, L., \& Rulli, D. (2006). A Time-Series Analysis of the Demand for Life Insurance Companies in Australia: An Unobserved Components Approach. Australian Journal of Management, 31, 41-66. https:/doi.org/10.1177/031289620603100104

Lewis, F. (1989). Dependents and the Demand forLife Insurance. American Economic Review, 79(3), 452-466.

Li, D., Moshirian, F., Nguyen, P., \& Wee, T. (2007). The Demand for Life Insurance in OECD Countries. The Journal of Risk and Insurance, 74(3), 637-652. https:/doi.org/10.1111/j.1539-6975.2007.00228.x

Lim, C., \& Haberman, S. (2004). Modelling Life Insurance Demand from a Macroeconomic Perspective: The Malaysian Case. Research Paper: The 8th International Congress on Insurance, Mathematics and Economics, Rome.

Nesterova, D. (2008). Determinants of the demand for life insurance: Evidence from selected CIS and CEE countries. Institute of Economy and Forecasting, National Academy of Sciences of Ukraine.

Outreville, J. (1996). Life Insurance Markets in Developing Countries. Journal of Risk and Insurance, 63(2), 263-278. https:/doi.org/10.2307/253745

PNUD. (2014). Pérenniser le progrès humain: Réduire les vulnérabilités et renforcer la résilience. Rapports sur le développement humain. https:/doi.org/10.18356/6e03c6f5-fr

UEMOA. (2008). Rapport annuel de la Commission sur le fonctionnement et l'évolution de l'Union.

UEMOA. (2008-2014). Rapport annuel de la Commission sur le fonctionnement et l'évolution de l'Union. Rapport d'activité. Retrieved from http://www.uemoa.int

Ward, D., \& Zurbruegg, R. (2000). Does Insurance Promote Economic Growth? Evidence from OECD Countries. Journal of Risk and Insurance, 67, 489-506. https:/doi.org/10.2307/253847

Ziguélé, M. (2008a). Comment renforcer les compagnies d'assurances africaines de la zone CIMA. CAPafrique - Analyses sectorielles.

\section{Notes}

Note 1. Lelart (2002) describes in more detail the implications of informal finance development in poor countries.

Note 2. Browne and Kim (1993) and Beck and Webb (2003) found a negative relationship between the life insurance application and Islam.

Note 3. Sharia represents various doctrinal standards, social, cultural, and relational enacted by the "Revelation". The term used in Arabic in the religious context means "way to enforce the law [of God]".

Note 4 . These countries are all members of FANAF and governed by the same insurance Code (CIMA).

Note 5. The real interest rate $=($ interest rates of deposits - inflation $) /(1+$ inflation $)($ Nesterova, 2008) .

Note 6. World Bank: the population growth rate is 2.8 Madagascar, 2, $5 \mathrm{R}$. Guinea, 2.8\% the CEMAC countries and $3 \%$ for the WAEMU.

Note 7. Human Development Report (2014).

Note 8. Islamic canonical law governing religious, political, social and individual, strictly enforced in some Muslim states. 
Note 9. The number of life insurance companies is estimated, in 2016, to 194 against 164 in 2013 and 115 in 2004.

\section{Copyrights}

Copyright for this article is retained by the author(s), with first publication rights granted to the journal.

This is an open-access article distributed under the terms and conditions of the Creative Commons Attribution license (http://creativecommons.org/licenses/by/4.0/). 